\title{
Susceptibility to oil spill spreading using case studies and simulated scenarios
}

Caroline Barbosa Monteiro ${ }^{\mathrm{a}, *}$, Phelype Haron Oleinik ${ }^{\mathrm{b}}$, Thalita Fagundes Leal ${ }^{\mathrm{b}}$, Eduardo de Paula Kirinus ${ }^{\mathrm{b}}$, Elírio Ernestino Toldo Júniorc ${ }^{c}$ Wiliam Correa Marques ${ }^{\mathrm{d}}$, Bruna de Carvalho Faria Lima Lopes ${ }^{\mathrm{e}}$

\footnotetext{
${ }^{a}$ Postgraduate Program in Oceanology, Institute of Oceanography, Federal University of Rio Grande, Rio Grande, RS, Brazil ${ }^{b}$ School of Engineering, Federal University of Rio Grande, Rio Grande, RS, Brazil ${ }^{c}$ Institute of Geosciences, Federal University of Rio Grande do Sul, Porto Alegre, RS, Brazil

${ }^{d}$ Institute of Mathematics, Statistics and Physics, Federal University of Rio Grande, Rio Grande, RS, Brazil

${ }^{e}$ Civil and Environmental Engineering Department, University of Strathclyde, Glasgow, Scotland, United Kingdom
}

\begin{abstract}
Fossil fuels still prevail over other energy sources in the world's consumption energy matrix. Thus, oil transportation and operations over maritime routes have been in high demand for a long time. Although oil spill accidents caused by these activities have reduced significantly over the last few decades, they still cause great concern. From this perspective, this paper presents simulation analyses of oil spill case studies using TelEmac-3D hydrodynamic model coupled with an oil model. Hence a location susceptible to such accidents was selected and three real oil spills were simulated, for each of which there were official technical monitoring reports available. The obtained results contribute to the knowledge of oil pollution susceptibility in environmentally sensitive areas, as well as provide information concerning oil slick behaviour. Additionally, similarities between the modelled results and the technical reports were confirmed. These findings are useful for contingency planning and responding to these probable accidents.
\end{abstract}

Keywords: Oil spill modelling, Susceptibility, Environmentally Sensitive Areas.

\section{Main finding}

This study provided knowledge of oil spill spreading in environmentally sensitive areas.

\section{Introduction}

Oil spills generate negative environmental impacts and liabilities (Cormier and Magnan, 1997) in the ocean ecosystems and coastal communities (Beyer et al., 2016), threatening environmental safety (Lee and Jung, 2015; Azevedo et al., 2017), human health (Osofsky et al., 2011; Gohlke et al., 2011) and socioeconomic activities (Sumaila et al., 2012). These casualties can trigger processes such as bioaccumulation and biomagnifications in organisms (D'adamo et al., 1997; Wang et al., 2019); increase aquatic and sediment toxicity (Xia et al., 2019; Struch et al., 2019; Akinola et al., 2019; Yoon et al., 2019); and also expose humans to severe and chronic toxicity (Wells et al., 1999) through swallowing, skin contact and inhalation (Noh et al., 2019).

Maritime transport is the main route of intercontinental oil and tradable goods, and oil spills continue to take place throughout the world (Lee and Jung, 2015; Ha, 2018), but more frequently in medium or small scales. Unfortunately, reliable reporting of small spills is often difficult to achieve as data available are often incomplete (ITOPF, 2018).

International agreements have been formulated, although not all maritime nations have been committed (Portmann and Connor, 1968), in an endeavour to significantly reduce oil pollution. Indeed, in response to a series of tanker incidents between 1976 and 1977, the International Convention for the Prevention of

\footnotetext{
*Corresponding Author
} 
Marine Pollution from Ships (MARPOL) was created. Its regulations have been designed to help prevent and minimise discharges during routine operations, as well as to combat oil spill threats (Ventikos et al., 2019).

Currently the most frequent types of smaller scale oil spills recorded have been caused by allisions, collisions, groundings, hull failures, equipment failures, fires and explosions and others such as heavy weather damage and human error (ITOPF, 2018). According to Michel and Fingas (2016) human errors (30 to 50\%) and equipment failures (20 to $40 \%$ ) have the highest likelihood of occurrence.

Thus, despite of worldwide marine oil spill safety initiatives, the possibility of an accident cannot be eliminated, consequently, proper planning for these events is highly recommended to minimise the negative impacts they generate. Thereby, prior knowledge of the susceptible areas should contribute to efficient spill containment and the selection of clean-up techniques to be used in case of oil spill. This information is usually obtained from aerial surveillance that allows to assess the spill situation and to generate useful information to guide response actions straight after the spill detection (Allen and Walsh, 2008; Berry et al., 2012).

With an efficient and fast prediction of the nature and scale of the problem, it may be possible to use different strategies for oil response at sea, as well as the containment and recovery, using equipment as booms, skimmers and sweeping arms, dispersants and in situ burning (ITOPF, 2014a,b,c; Guo, 2017). These techniques can be used as soon as an accident is reported, reducing the likelihood of oil pollution in environmental restricted areas as well as help determining priorities for protection in order to maximise effective use of available equipment.

Oil spill displacement and fate models are effective tools which allow a spatial-temporal explicit reconstruction of oil spills, while accounting for key processes such as evaporation and emulsification (Berenshtein et al., 2019).

Marine oil spills modelling allows describing the movement of oil slicks under realistic scenarios and may generate useful information to back up contingency interventions and practitioners (Alves et al., 2014, 2015; Luan et al., 2019; Meng et al., 2019), for example, as the different oil slicks behave against the oil weathering processes in scales of hours up to days after the spills (Monteiro et al., 2019).

Thus, one of the challenges for oil contingency is to provide motivation for developing better response methods based on the understanding of oil interaction with seawater under different environmental conditions. When crude petroleum products are released into the sea, they are immediately subjected to a variety of weathering processes able to modify their properties (Øksenvåg et al., 2019). Such changes also affect oil fate and behaviour, and have implications in the spill clean-up or contingency, reinforcing the importance of investigating oil weathering.

As a primary weathering process, involved in the natural removal of oil from the sea surface is evaporation. It acts stronger in the first 24 to $48 \mathrm{~h}$ after a spill (Institute, 1999). Usually evaporation removes the most volatile fractions of the spill in a few hours, and it is influenced mainly by wind speed and spill area and size (Fingas, 1995, 1999).

Subsequently to the evaporation, the emulsification is another important process of weathering (Reed et al., 1989; Fingas et al., 2001). It expands the volume of pollution (Fingas, 1999) and affects the exchange processes between the sea surface and the layer of air above it. While evaporation reduces the drifting oil mass, emulsification increases the oil slick size and also the hydrocarbon density and viscosity which in turn attenuates the evaporation rates (Fingas, 1997; Fingas and Brown, 2018; Mishra and Kumar, 2015).

Even though the medium $(7-700 \mathrm{t})$ and large $(>700 \mathrm{t})$ scale spills have been shown stronger downward trends over the last 49 years (ITOPF, 2018), $80 \%$ of the incidents recorded since 1970 are classified as small (less than $7 \mathrm{t}$ ). Thus, an effort was made, in this study, to estimate the extension of the areas susceptible to the effects of oil pollution, especially those resulting from small-sized spills.

\section{Dataset and methods}

A detailed description of the methodology with data sources used and validation steps are presented in the Supplementary Material. 


\subsection{Study area}

Oil slicks resulting from real oil spills in the Southern Brazilian Shelf (SBS, fig. 1-a) were investigated since it was possible to recover historical information of accidents in this area. The vicinities of Imbé and Tramandaí are vulnerable to accidental oil spill as a consequence of the presence of oil collector buoys (MN-602, fig. 1-b), type Single Buoy Mooring (SBM), connecting the oceanic oil Almirante Soares Dutra Terminal (TEDUT) to Alberto Pasqualini Refinery (Refap) in Porto Alegre city. Both places are also particularly exposed as a result of the traffic of ships to and from Rio Grande city harbour (Marques et al., 2017).

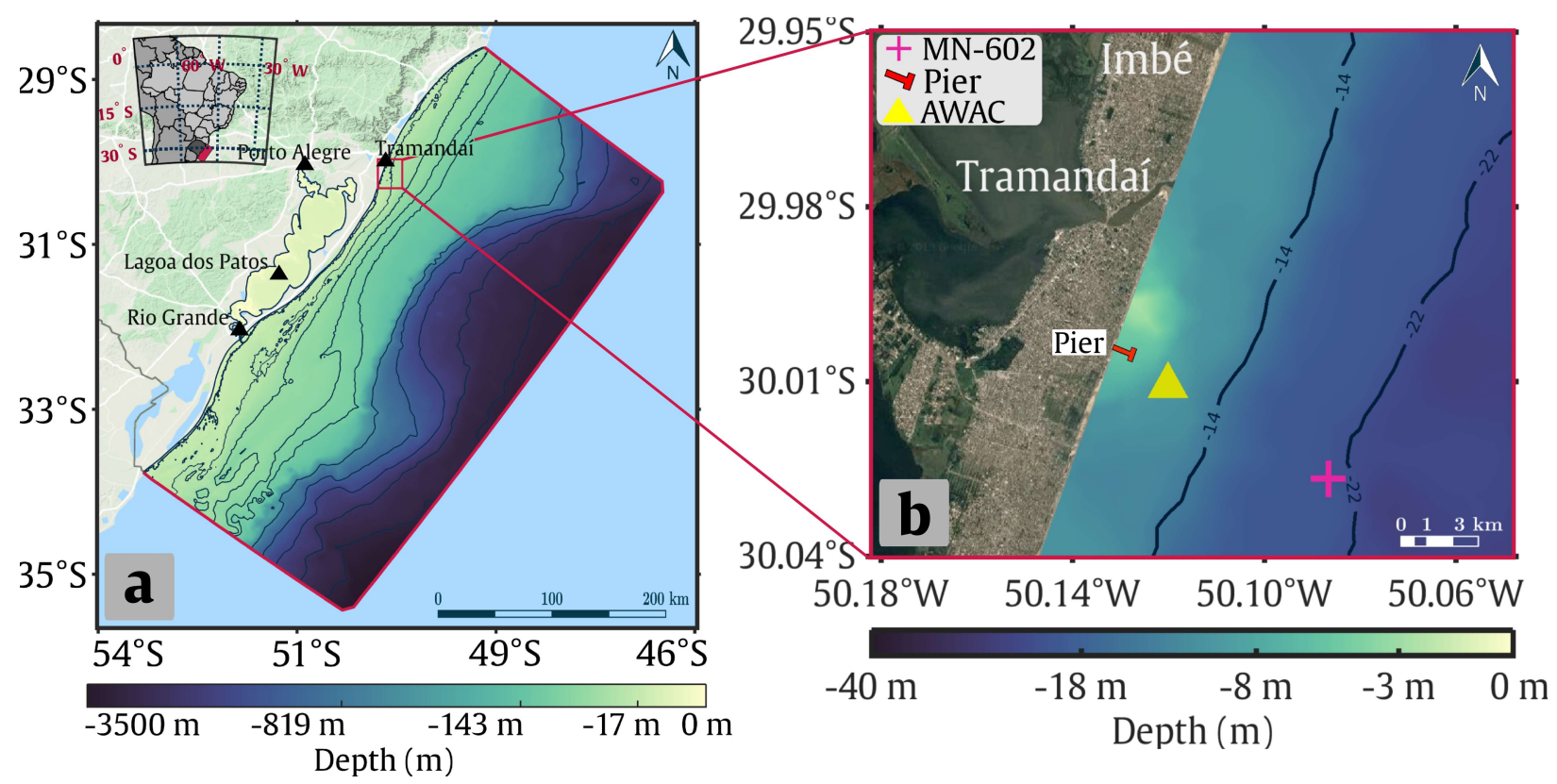

Figure 1: SBS outlined in red (a) and bathymetry by the colour bars. Red box (b) defining the specific area, while the pink " + " symbol points out the MN-602 and the AWAC equipment near Tramandaí coastal zone (yellow triangle) on Google Earth@) image.

Extending from latitude $34^{\circ} \mathrm{S}$ to $22^{\circ} \mathrm{S}$, the SBS constitutes the only part of the Brazilian shelf with a subtropical to temperate climate (de Mahiques et al., 2010). It is a wide continental shelf with intense coastal currents and large mesoscale variability, generated by bathymetric or meteorological factors, such as the local winds, the micro-tidal behaviour (Möller Jr et al., 2001) and the constant influence of weather fronts (Dereczynski and Menezes, 2015). The coastal circulation occurs predominantly parallel to the shore, forced by the incidence of wind (Zavialov et al., 2002), mainly by cold fronts stronger in winter (Stech and Lorenzzetti, 1992).

The coast of Rio Grande do Sul state in Brazil is formed by a long sandy barrier, with few interruptions, Northeast-Southwest oriented, controlled by the wave action with bidirectional coastal drift and winds in northeast direction (Calliari et al., 2009). The region of Tramandaí has mild slope beaches; morphodynamically classified as intermediate to dissipative; with the formation of well-developed frontal dunes (Tomazelli and Villwock, 1992) and a medium sensitivity to the influence of oil (Nicolodi, 2016).

Installed in the open sea, the single buoy MN-602 (fig. 1-b) is designed for the mooring of ships in the loading and unloading operations of oil and other products derivatives of oil, in particular, naphtha, diesel, petrochemical condensate and gasoline. This type of buoy is suitable for operations under adverse sea conditions, such as on continental shelves where the conditions of waves, winds and sea currents acting on the vessel might reduce the capacity of operation of the system (Horn, 1969). 


\subsection{Coupling between ECOS and TELEMAC-3D}

This oil modelling setup is composed of a free and open source software (TELEMAC-3D), and an oil model licensed by Federal University of Rio Grande (FURG), developed by former students of this institution for academic purposes.

TELEMAC-3D solves the hydrostatic Navier-Stokes equations under Boussinesq approximation together with the transport equations for scalar quantities of salinity and temperature. Finite element method was employed to solve the hydrodynamic equations, using sigma coordinate system for vertical discretization to represent the sea surface height and the seabed (Hervouet, 2007).

Results from the three-dimensional hydrodynamic model, such as currents, salinity and temperature fields, were used by ECOS oil-spill model to calculate the weathering processes and the oil transport.

ECOS represents an oil slick as a set of discrete particles, the displacement and properties of which are updated at each time step considering changes in oil properties and hydrodynamic conditions (Mello et al., 2011; Stringari et al., 2013; Monteiro et al., 2017; Marques et al., 2017). The oil model used takes into account the oil slick evaporation using the algorithms of Stiver and Mackay (1984) and Fingas (1995, 1999), with empirical coefficients obtained from Lehr et al. (2002). For the emulsification process, ECOS uses a first-order differential equation proposed by Mackay et al. (1980) to consider the maximum emulsification for a light type of oil and other empirical constants according to Mackay et al. (1982). Mass changes in the oil slicks are based on emulsification and evaporation processes.

\subsection{Hydrodynamic variability analyses}

TELEMAC-3D was used to perform hydrodynamic simulation for 9 years in order to identify the major time scales in which the most relevant processes occur and its implications for the oil pathway.

Cross-wavelet analyses were carried out according to Torrence and Compo (1998) methodology to allow the analyses of energy distribution of winds and current velocity time series of modelled data. Also, these cross-wavelet analyses were aiming at identifying the time scale of the cross-correlation that the effect of the winds exerts at local currents due to its relevance for the oil modelling. The time series were evaluated in frequency, time and spatial domains.

\subsection{Oil spill cases}

The oil spill starting points of the three accidents simulated were located at MN-602 buoy $\left(30^{\circ} 1^{\prime} 36^{\prime \prime} \mathrm{S}\right.$; $50^{\circ} 5^{\prime} 12^{\prime \prime} \mathrm{W}$ ) operated by Transpetro company, about $6 \mathrm{~km}$ from Tramandaí fishing pier (fig. 1-b).

The initial oil density $\left(915 \mathrm{~kg} / \mathrm{m}^{3}\right)$, seawater density $\left(1,025 \mathrm{~kg} / \mathrm{m}^{3}\right)$ and API degree ${ }^{1}\left(23.1^{\circ}\right)$ on the arbitrary scale that measures the density of petroleum derived liquids, were used as initial conditions for all oil simulations. A maximum value of $75 \%$ (Mackay et al., 1982), corresponding to the maximum emulsification expected for the type of heavy oil fuel simulated, was used. The oil amounts were obtained through reference reports from the actual spills, where the largest $\left(13.53 \mathrm{~m}^{3}\right)$ is associated with the event of $26^{\text {th }}$ January 2012 (FEPAM, 2012). The remaining events started on 11.45 PM on the $3^{\text {rd }}$ July 2014 and on $6^{\text {th }}$ April 2016, both with the same initial volume $\left(4 \mathrm{~m}^{3}\right)$ of oil spilt (FEPAM, 2014, 2016).

Furthermore, although the oil spills were monitored for the first $24 \mathrm{~h}$ after the beginning of the three events, simulations were extended to $48 \mathrm{~h}$ after each spill aiming at a detailed investigation of the susceptibility to oil contamination. To examine the potential spatial distribution of marine oil spills on the SBS, the probability of the oil spill pollution was estimated assuming three points for the start of the simulations, totalling 2,897 oil spill events. Oil spill-susceptible areas were analysed and the probability of pollution hazard was mapped using TerraView ${ }^{2}$. The strategy of the simulations in this study was aimed at modelling susceptibility from only the most striking processes in the first hours after a spill, such as evaporation and emulsification. Presently there are some limitations in this modelling setup. For instance, this methodology does not include the variations in oil composition, the processes of natural dispersion or other weathering processes. These predominate beyond the period for which the monitoring of this study is focused on, when continuous monitoring pollution is still mandatory (Urbahs and Zavtkevics, 2020).

\footnotetext{
${ }^{1}$ Created by the American Petroleum Institute (API), along with the National Bureau of Standards, the API Gravity Scale allows the measurement of the relative density of liquids. The higher the oil density, the lower its API degree.

${ }^{2}$ http://www.obt.inpe.br/OBT/assuntos/projetos/terralib-terraview
} 


\section{Results}

\subsection{Background hydrodynamic for oil modelling}

Since the velocities of winds and currents are the main physical effects of oil behaviour in the study area (Janeiro et al., 2008; Stringari et al., 2013; Marques et al., 2017; Monteiro et al., 2017; Kirinus et al., 2018), the spill simulations were analysed considering such geophysical variables.

A one-dimensional cross-wavelet was applied in order to identify the time scales most relevant to processes acting in the study area. fig. 2 presents the Wavelet Power Spectrum (WPS) illustrating the energy distribution of the winds and current velocities of modelled data. This analysis shows the time scale of the cross-correlation that winds exerts on local currents.
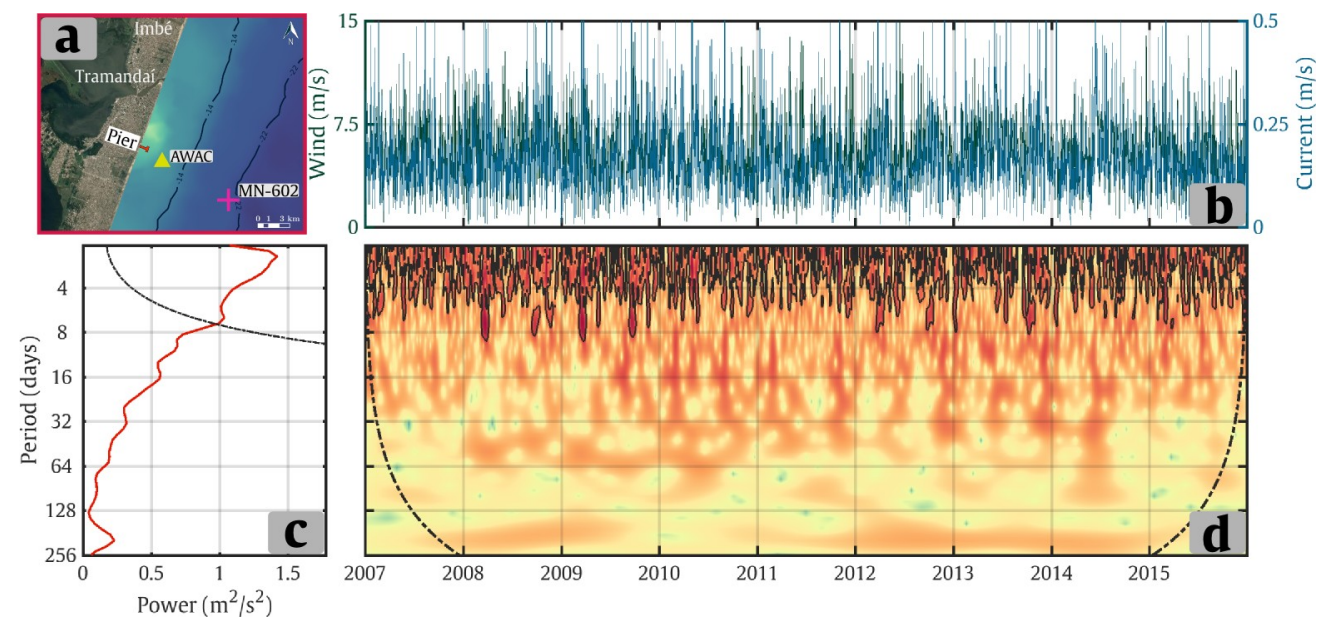

Figure 2: The point from the time series in pink "+" symbol (a), time series of the intensity of the wind and zonal component of currents (b), global wavelet power spectra (c), and the local cross-wavelet spectra (d).

The time series were obtained from a hydrodynamic simulation of 9 years $(2,007-2,015)$, considering only the oscillation periods between 1 and 126 days, which better represents the processes associated with the wind influence on coastal currents of the study area (indicated by the red zones within the black contour lines in fig. 2 (d), according to previous studies in the region (Parise et al., 2009; Andrade et al., 2016).

For both the global (fig. 2-c) and the local energy spectrum (fig. 2-d), the ordinate indicates the period, in days, for the variability representation of the frequency of the signals in the time domain.

The curve represented by the black dotted line (fig. 2-d) delimits the influence cone, which excludes frequencies that may be neglected due to the absence of statistical confidence (95\%). The zones with warmer colours inside the black dotted line (fig. 2-d) define the band of the frequency spectrum of greater energy variability along the time domain.

The results show that the energy concentration is higher over a short time period (fig. 2-d), increasing the dominance of the dynamic processes with period between 4 and 8 days. Although this result contains 9 years of simulation (abscissa of fig. 2-b and d), it points out that low-inertial wind and current regulating processes (less than 8 days) tend to control the most energetic dynamic pattern processes for the region considered.

Hence, fig. 2-c shows a high degree of significance for processes with less than 8 days which are possibly associated with large-scale pressure systems acting on the SBS, such as the Polar Anticyclone - specially between autumn and winter (Stech and Lorenzzetti, 1992; Saraiva et al., 2003; Parise et al., 2009) and the Atlantic Anticyclone, whose effects are most expressive during spring and summer (Hasenack and Ferraro, 1989), generating dynamic variations in the winds associated with pressure gradient forces capable of acting on the behaviour of coastal currents (da Rocha et al., 2004; Andrade et al., 2016).

For a broader perspective, a two-dimensional wavelet analysis was also made, comprising the period bands between 4 and 8 days (fig. 3-a), presented as the most relevant, dealing with the correlation of the 


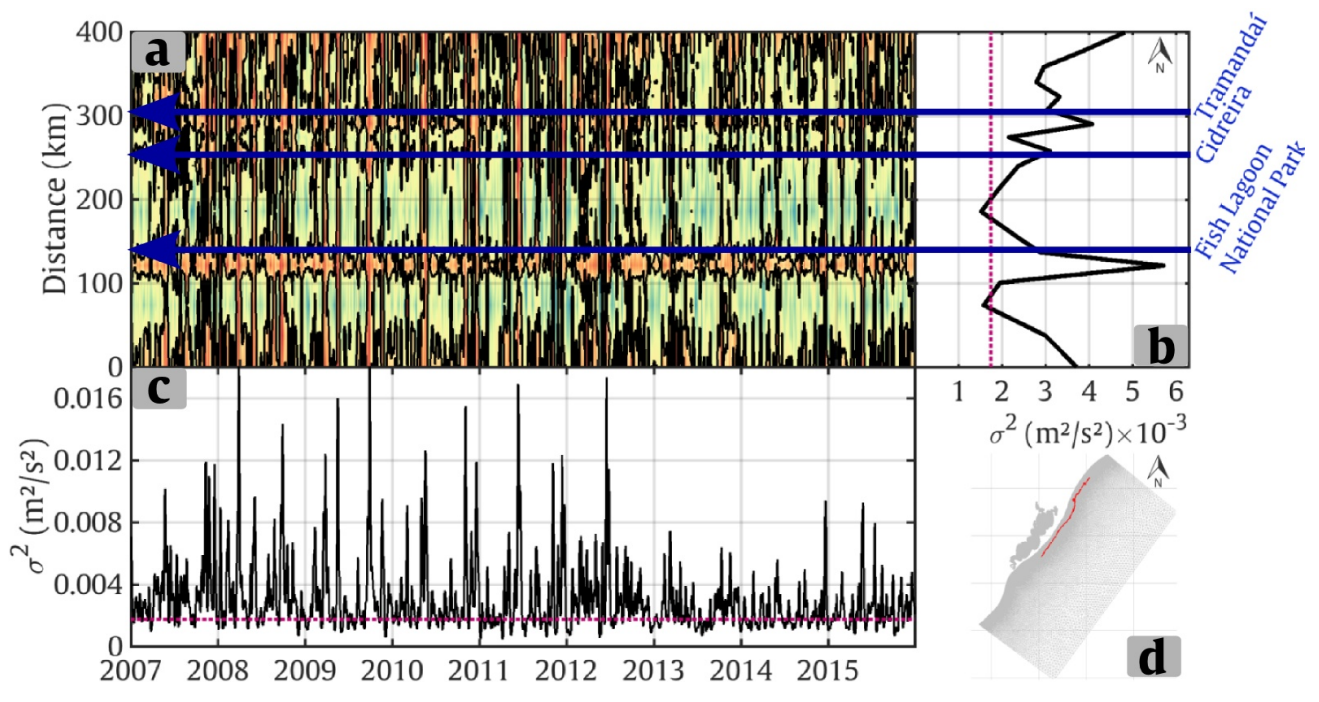

Figure 3: Two-dimensional local wavelet power spectrum (a) for average signals of 8 days of wind velocity (m/s) in points located in the $30 \mathrm{~m}$ isobar; (b) Mean-variance for the analysed period whose values below purple dotted line indicated those with statistical confidence (95\%); (c) Time series with the mean-variance for each point considered, and (d) Cross-section in the red line representing the analysed points of the numerical domain.

effect of winds on coastal currents, as shown in the one-dimensional wavelet (fig. 2)) and by similar studies (Stringari et al., 2013; Marques et al., 2017; Monteiro et al., 2017).

This spatial variability analysis of the wind effect was evaluated along a $400 \mathrm{~m}$ long cross-section at the $30 \mathrm{~m}$ bathymetric line (ordinates in fig. $3-\mathrm{a}$ and $\mathrm{b}$ ), covering both the region of the oil simulations and its surroundings potentially susceptible to the effects of pollution generated by these accidents.

Energy peaks throughout the evaluated cross-section were also identified, some of them, indicated by blue arrows, highlighting localities for spatial reference purposes (fig. 3-a and b) within $95 \%$ of confidence (fig. 3-c). The region of simulated spills is located near Tramandaí, highlighted in blue at the $300 \mathrm{~km}$ mark (ordinates in fig. 3-a and b). For instance, this region is an example of a high energy area coupled with high variability of incident winds in the frequency domain of signals with periods up to 8 days in the local spectrum (colour bar in fig. 3-a).

\subsection{Susceptibility}

An estimation of the oil contamination susceptibility was applied in the analyses performed herein towards the use of polygons to group and outline oil particles in water, adapted from Alves et al. (2014, 2015); Marques et al. (2017); Lopes et al. (2019); Monteiro et al. (2019); Leal et al. (2019). The Littoral Sensitivity Indexes (LSI) from the Brazilian Oil Sensitivity Charts (SAO charts) of Pelotas Basin (MMA, 2002; Nicolodi, 2016) were used in this section. The LSI classifies the coastlines according to an environmental sensitivity scale ranging from 1 , the lowest, to 10 , the highest sensitivity. This index considers the levels of exposure to wave and tidal energy, the slope of the coast and the type of substrate (Jensen et al., 1998; Petersen et al., 2002; Wieczorek et al., 2007).

The oil spill event analysed started at 12 PM on $26^{\text {th }}$ January 2012 during an unloading operation from the Elka Aristotle vessel to Transpetro buoy (MN-602, fig. 1-b), a rupture of a safety valve of the breakaway coupling type installed in the floating buoy sleeves took place, resulting in about $13.53 \mathrm{~m}^{3}$ of oil being spilt and spread in the vicinity of Tramandaí fishing pier, near Tramandaí lagoon inlet. This event was simulated and presented in fig. 4.

fig. 4 (a) shows that $4 \mathrm{~h}$ after the spill started, $4 \mathrm{PM}$ local time, the emulsion spread over an area of $3.9 \mathrm{~km}^{2}$ along the coastal waters, which was comparable to the $3.36 \mathrm{~km}^{2}$ indicated in the technical report of this oil spill event (FEPAM, 2012). At 5 PM, $5 \mathrm{~h}$ after the start of the spill, the area of oil coverage increased 


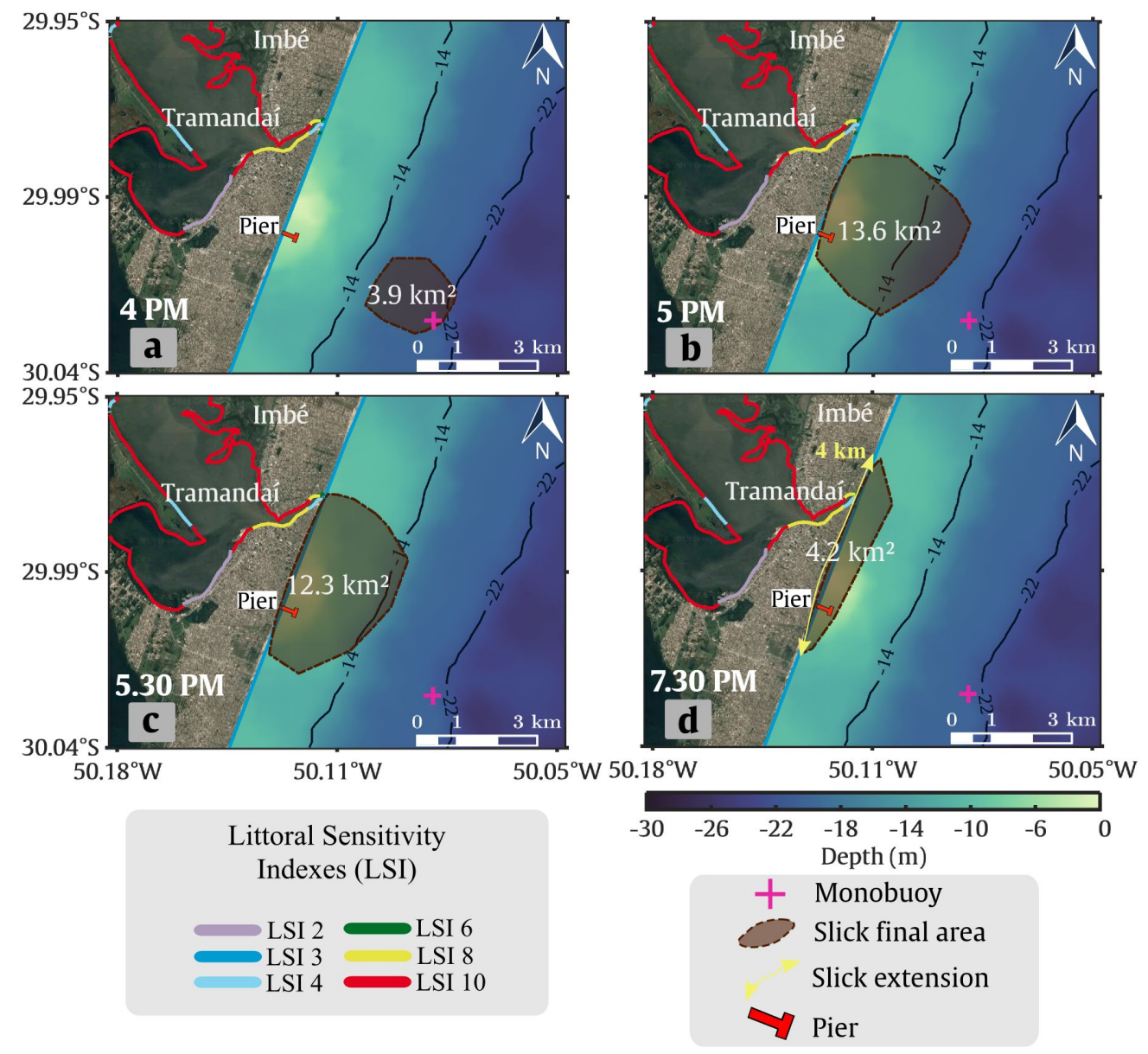

Figure 4: Snapshots of the susceptibility polygons (in brown) for the event of 12 PM on $26^{\text {th }}$ January 2012 . Bathymetry indicated by a colour gradient on top of Google Earth(c) image, and LSI from Nicolodi (2016). Number of hours after oil spill event for each panel: (a) $4 \mathrm{~h}$; (b) $5 \mathrm{~h}$; (c) $5 \mathrm{~h}: 30 \mathrm{~min}$ and (d) $7 \mathrm{~h}$.

to $13.6 \mathrm{~km}^{2}$ and reached the beach (fig. 4-b), then between the $5^{\text {th }}$ and $6^{\text {th }}$ hours after the spill (fig. 4-c) the oil started to spread along the shore, which is also in agreement with the technical report (FEPAM, 2012).

Hence, around $7 \mathrm{PM}$ on $26^{\text {th }}$ January 2012 , the pollution reached the beach stretch between the pier and Tramandaí lagoon outlet, approximately $4 \mathrm{~km}$ long (fig. 4-d), equivalent to the $3.5 \mathrm{~km}$ recorded in the technical report (FEPAM, 2012). The final simulated area was $4.2 \mathrm{~km}^{2}$ of oil contamination positioned along the coastline, which happened $7 \mathrm{~h}$ after the simulation starting time.

This final area (fig. 4-d), is distributed in a $4 \mathrm{~km}$ long oil slick along the shore, which corresponds to pollution covering more than $15 \%$ of the combined beach line of Tramandaí and Imbé altogether $(25.3 \mathrm{~km})^{3}$.

In 2014, another spill occurred at the same location, at $11.45 \mathrm{AM}$ on $3^{\text {rd }}$ July, during shipping operations of tanker Pinnacle Spirit. This spill was a result of the mooring line from the ship to the buoy breaking due to strong wind gusts.

Although the pollution was controlled within $24 \mathrm{~h}$ after the spill (FEPAM, 2014), the simulation lasted $48 \mathrm{~h}$, showing the movement towards open sea. The conditions of the oil slick movement were favourable to the use of physical and chemical methods of dispersants among other spill containment and clean-up techniques.

${ }^{3}$ http://www.tramandai.rs.gov.br/index.php?acao=conteudo\&conteudos_id=12 
According to the technical report (FEPAM, 2014), at the end of the oil containment efforts, there were no visible impacts or signs indicating oil contamination in the coastline or open sea, which was also observed in the modelled results (fig. 5). It is worth pointing out that, the chemical and mechanical dispersion processes have not been included in the simulations.

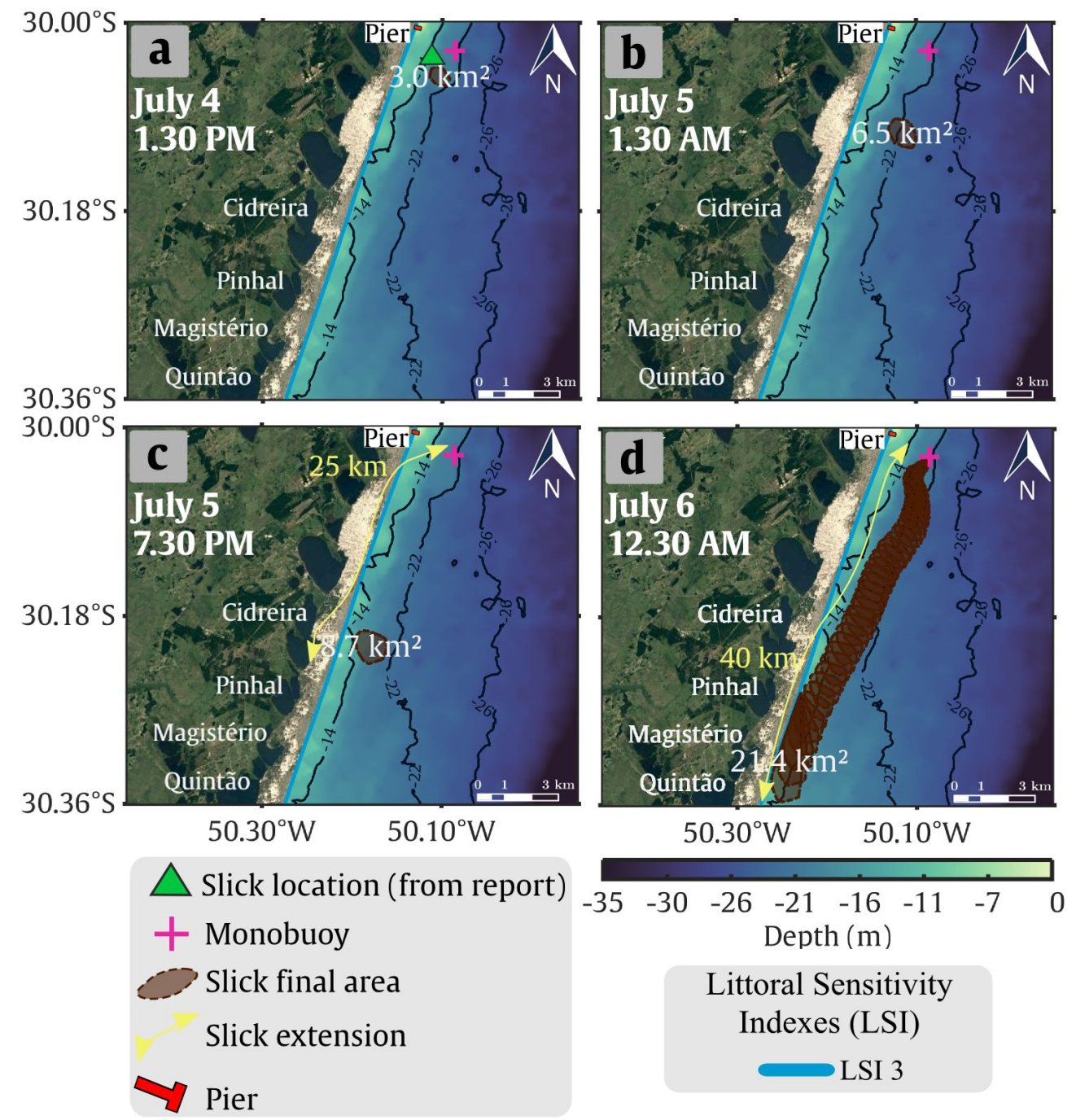

Figure 5: Snapshots of the susceptibility polygons (in brown) for the event of $11.45 \mathrm{Am}$ on $3^{\text {rd }}$ July 2014. Bathymetry indicated by a colour gradient on top of Google Earth@ image, and LSI from Nicolodi (2016). Number of hours after oil spill event for each panel: (a) $14 \mathrm{~h}$; (b) $26 \mathrm{~h}$; (c) $33 \mathrm{~h}$ and (d) $48 \mathrm{~h}$.

The accuracy of the 2014 modelled spill was demonstrated by the agreement between the precision in the positioning of the oil slick resulting from this study and the coordinates of the actual oil slick obtained during one of the monitoring flights $\left(30^{\circ} 1^{\prime} 29.15^{\prime \prime} \mathrm{S} ; 50^{\circ} 6^{\prime} 37.22^{\prime \prime} \mathrm{W}\right)$ at $14 \mathrm{~h}$ after the spill, indicated by the green triangle in fig. $5-$ a.

The information about the $48 \mathrm{~h}$ of the spill is in part speculative, since the technical report of the spill monitored in detail only the $24 \mathrm{~h}$ following the accident. Nevertheless, based on realistic hydrodynamic conditions, this additional $24 \mathrm{~h}$ (fig. 5-c, d) may represent a good approximation of the extent of pollution arising from failures in oil control activities or even changes in the necessary conditions for the use of the chemical dispersants, as observed during the works to control the oil spilt (FEPAM, 2014).

Therefore, after $33 \mathrm{~h}$ from the beginning of the oil spill (fig. $5-\mathrm{c}$ ), at $7.30 \mathrm{PM}$ of the day after, the path of 
the oil slick would be redirected gradually from the direction of movement offshore and parallel to the shore to a progressive movement towards the coastal waters. In the scenario described, the susceptibility polygons would advance towards the coastline covering an extension of approximately $25 \mathrm{~km}$ from the starting point, as indicated by the yellow arrow. Thus, part of the pollution would reach beaches in the cities of Pinhal and Magistério, besides a segment near Quintão city.

The third spill simulated occurred around 8.30 PM on $6^{\text {th }}$ April 2016, during transhipment activities between an oil tanker off the coast of Tramandaí and the same buoy of the previous accidents described.

The oil slick was directed offshore for $48 \mathrm{~h}$ (fig. 6), travelling a close range of $30 \mathrm{~km}$ after conditions of prevailing winds and currents. This event caused possibility fewer damages, since its susceptibility polygons increased into open sea waters.

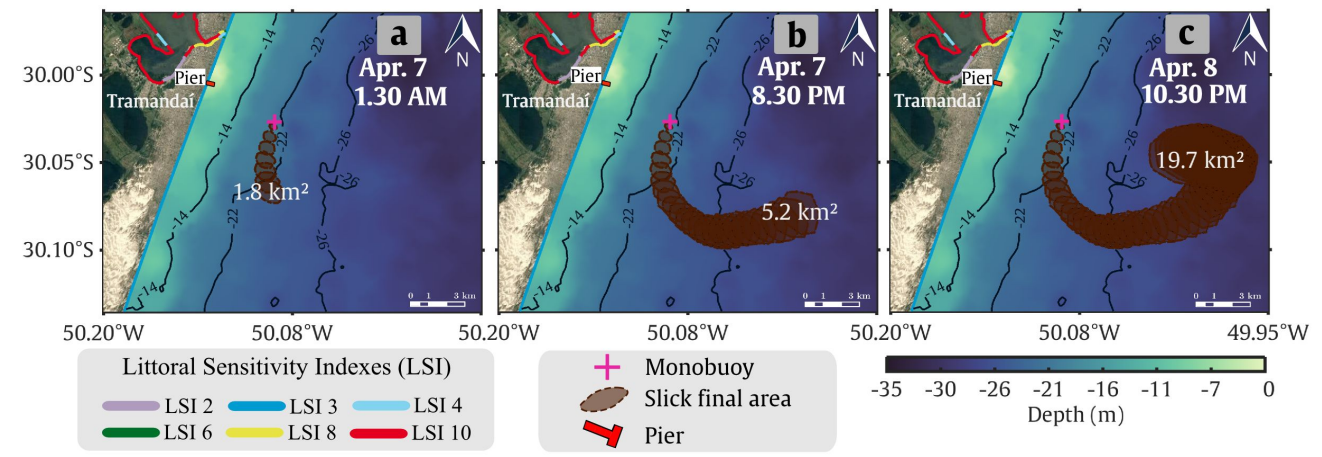

Figure 6: Snapshots of the susceptibility polygons (in brown) for the event of 10.30 PM on $6^{\text {th }}$ April 2016 . Bathymetry indicated by a colour gradient on top of Google Earth(c) image, and LSI from Nicolodi (2016). Number of hours after oil spill event for each panel: (a) $3 \mathrm{~h}$; (b) $22 \mathrm{~h}$ and (c) $48 \mathrm{~h}$.

As a result of that, the initial oil load spread into deep waters, favouring the natural depuration of pollution in the course of $48 \mathrm{~h}$ of monitoring, as indicated by the technical report. Beyond that, the slicks have moved away from environmentally sensitive areas. Therefore, the model outputs were equivalent to the technical report information provided by the Brazilian Environment Agency FEPAM (FEPAM, 2016) during the first $24 \mathrm{~h}$ following the spill (fig. 6-a, b).

The simulated oil movement and behaviour agree with some results from previous studies (Mello et al., 2011; Stringari et al., 2013; Marques et al., 2017), in which the advection of oil occurs mainly due to the effect of local winds and the direction and intensity of coastal currents.

Finally, the behaviour of oil slicks was also analysed. However, it was not possible to establish comparisons between the results of the oil weathering modelled with real information, since these latter have never been recorded. The higher evaporation rates correspond to the slicks with the largest spreading areas (fig. 7-A), as also verified by Fingas (1995). For all simulated cases, evaporation increased 3 to 4 times over the first $24 \mathrm{~h}$, corresponding to the highest oil spreading rates in coastal waters.

The mass increase of the water-in-oil emulsion followed the evolution of emulsification rates for the first $4 \mathrm{~h}$ simulated (fig. 7-B), which reached the maximum value of $75 \%$ according to the maximal emulsification expected for the type of heavy fuel oil used in the simulations of the present study. Those are also in accordance with values obtained from weathering experiments done in the field for three types of oil (Mackay et al., 1982).

Since oil spills could happen at any time from anywhere next to the shipping routes, simulations based on only three oil spill events starting at one single location (MN-602) cannot provide extensive comprehensive information about oil contamination.

Therefore, in order to investigate the variability of oil distribution from marine leaks starting at the same point and under similar conditions to the case studies modeled, a set of 2,897 hypothetical daily oil spills distributed between 2007 and 2015 were simulated (fig. 8).

Hence, the modelling of oil slicks starting at the same spill point as the studied historical cases, allowed for the mapping of hazard probabilities (highest between 0.89 and 0.63 ) and also enabled the identification 

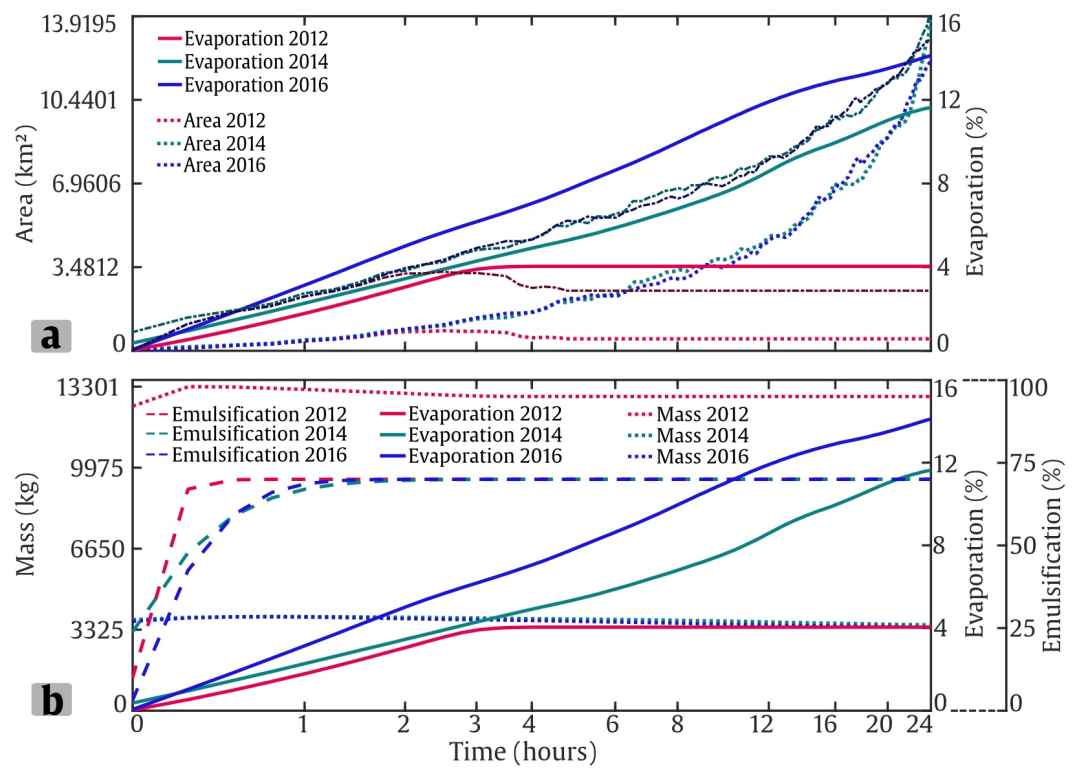

Figure 7: Oil slick areas versus evaporation rates (a), and emulsion mass versus evaporations and emulsification rates (b) for the events of: $26^{\text {th }}$ January 2012; $4^{\text {th }}$ July 2014 and $6^{\text {th }}$ April 2016.

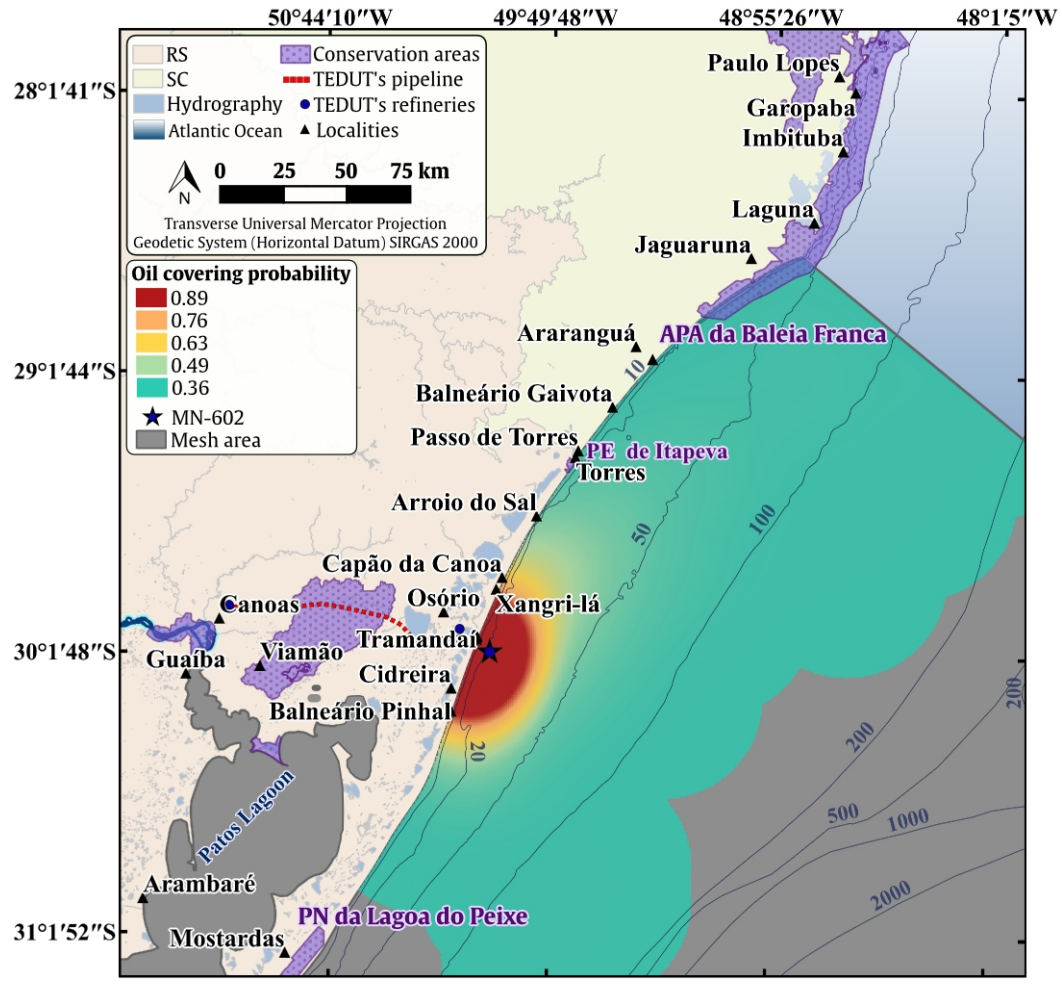

Figure 8: Oil covering hazard for the oil collector buoy (MN-602). 
of areas susceptibility to oil effects, which then enlarged the zones likely to be contaminated. These hazard areas were confined to smaller zones in the vicinities of Tramandaí and Imbé, reaching also important beaches in the region.

Furthermore, the inherent danger of oil dispersal in this shore face has resulted in threats over wider areas. Although, under relatively low pollution probabilities (0.49 to 0.36), oil particles reached environmental conservation sites, such as Lagoa do Peixe National Park and APA da Baleia Franca.

\section{Discussions}

This evaluation of spatial and time scale of the changes in the wind patterns (section 3.1) is important because it allows discriminating the regions most influenced by the variability of wind conditions, associated to warmer colours in the cross section outlined by the $2 \mathrm{D}$ wavelet (colour bar in fig. 3-a).

Such regions may need special attention regarding emergency oil spill plans since the winds and the coastal currents are the major forces contributing to the movement of oil (Stringari et al., 2013; Marques et al., 2017; Monteiro et al., 2017). Thus, abrupt changes in wind conditions may also cause variability of the areas susceptible to the effects of oil.

Other regions have also revealed considerable variability in wind conditions on the scale of a few days. Many of these areas have remarkable environmental sensitivity to contamination by oil spills, such as the areas near Peixe Lagoon National Park created in 1986, surrounded by the municipalities of Tavares, Mostardas and São José do Norte, with the aim to protect migratory bird species and specimens of the coastal ecosystems of Rio Grande do Sul (Pinheiro and da Silva, 2019).

Regarding the oil spill covering areas presented in section 3.2, for the event of 2012 (fig. 4) the modelled oil slick reached almost a third of the $12 \mathrm{~km}$ of Tramandaí beach, threatening neighbourhood areas with high LSI values (10, 8 and 4 - fig. 4), such as salt marshes, recreational and artisanal fisheries, dunes, tourism infrastructures, beaches and environmentally protected spaces. The modelled oil slick also reached zones of LSI-3 (Nicolodi, 2016), with substrates of medium permeability, moderate penetration and deposition of oil.

Furthermore, in accordance with the technical report (FEPAM, 2014), the simulated oil slick resulting from the 2014 spill, showed dominant movement towards the southeast and parallel to the shore (fig. 5-a, b) during the first $24 \mathrm{~h}$ following the spill.

In the aforementioned oil spill, after $48 \mathrm{~h}$ from the start of the event, a possible scenario would be one in which the oil would end up in the coastal strip, reaching about $40 \mathrm{~km}$ of displacement from the point of release (fig. 5-d, indicated by the yellow arrow). In this case, the susceptibility polygons would cover areas with LSI-3 and the resulting oil pollution could threaten urbanised areas important to tourism and other multiple use areas, as well as the quality of areas of ecological importance such as coastal lagoons, wetlands and natural dunes.

For the last case of historical oil spill reproduced (from 2016), the initial oil load spread into deep waters, favouring the natural depuration of pollution in the course of $48 \mathrm{~h}$ of monitoring, as reported by the technical report information provided by the Brazilian Environment Agency FEPAM (FEPAM, 2016) during the first $24 \mathrm{~h}$ following the spill (fig. 6-a, b).

In view of the above, minimum factors may promote changes in the oil pathways, as, for instance, variations in the direction of the incident winds that are capable of forcing the oil to more sensitive coastal areas. As presented in section 3.1 these changes are expected in the scale of 4 to 8 days for the study area as observed for spills simulated herein.

As the results presented, for the case of small spills, especially such as the ones occurred in 2014 and 2016 , wide areas of susceptibility to oil contamination were reached. On the other hand, for the spill of 2012 , the areas of susceptibility polygons were less extensive, despite the fact that part of the pollution generated has reached areas of high LSI values in the first $5 \mathrm{~h}$ after the starting of the oil spill.

Besides, considering the results of the studied historical set of cases in section 3.2 (fig. 8), the reliability of the susceptibility assessment could increase given a larger number of oil spill scenarios. Therefore, a stochastic approach would be more appropriate for this type of analysis, allowing varying also the start point of the oil spill along with the critical areas. 
None of the technical report associated with the three events examined presented estimates for weathering rates, so it was not possible to analyse the reproducibility of the model for such conditions. Although, an indication of the oil slick behaviour were obtained by correlation made between the evaporation and emulsification rates obtained in this paper and the results of studies under similar conditions. The evaporation losses of the oil mass oscillated between $4 \%$, after $3 \mathrm{~h}$, and $15 \%, 24 \mathrm{~h}$ after the release of oil. These values correspond to those reported by other studies in which heavy oil spills were examined, similar to the oil type considered in this paper. As verified by Fingas (1999), heavy or residual oil will only lose about $5 \%$ of their volume in the first few hours following a spill, and residual fuel oils as Bunker $\mathrm{C}^{4}$ (maximum density of $1,010 \mathrm{~kg} / \mathrm{m}^{3}$ ) at $15{ }^{\circ} \mathrm{C}$ hardly evaporates, only about $5 \%$ in a week (Fingas, 2011).

In addition, according to Fingas (1995), Stiver and Mackay's equation (Stiver and Mackay, 1984), that has been used by several oil spill models and also by the oil model used in this paper to predicts evaporation, represent most oils relatively well until time exceeds about $8 \mathrm{~h}$, after that, this equation tends to overpredict the evaporation rates of marine oil spills. According to Chao et al. (2001) after $5 \mathrm{~h}$ evaporation can generate oil mass losses between $4-5 \%$. The authors verified that this oil weathering process is greater in the first 1-2 days when about $36 \%$ of the oil mass is lost. Badri and Azimian (2010) verified that two days after a spill, due to emulsification effects, oil disperses to the water column; evaporations rates are attenuated; and the amount of evaporation $5 \mathrm{~h}$ after a spill event is about $8 \%$.

The emulsification rates also agree with the expected for the type of heavy fuel oil that was used in the simulations of the present study. The increase in emulsion mass represented by the dotted lines (left ordinate axis, fig. 7-B) follows a emulsification peak in the first hour of simulation, following the rapid growth of emulsification values, which varied from 40 to $74 \%$ of water content. After the first hours of simulation, low losses of mass resulted mainly due to the increase in evaporation rates. These values are in agreement with experiments carried out with the Automated Data Inquiry for Oil Spills (ADIOS-2) oil weathering model $(70 \%$ after $6 \mathrm{~h}$ and $90 \%$ after $24 \mathrm{~h})$ and Oil Weathering Model - OWM $(79.3 \%$ after $6 \mathrm{~h}$ and $79.7 \%$ after $24 \mathrm{~h}$ ) using similar oil (Vos, 2005).

The emulsification curves represent a limitation of the coefficient implemented in the model (Mackay et al., 1982), which tends to stabilize emulsification at $75 \%$ for crude and heavy oils; this may not be representative of real conditions (McLean and Kilpatrick, 1997; Djuve et al., 2001). These curves indicated that the algorithms that describe this process in the model used here, adapted from (Mackay et al., 1980), need to be improved, either to not stabilize these rates at a level based on a coefficient, or to take into account the resin and asphaltene content.

Hence, the modelled results of evaporation, emulsification and mass increase of the water-in-oil emulsions also shown to be consistent with reference literature values. This information contributes with the understanding of the oil slicks behaviour due to small-scale accidents, which although more frequent, are still poorly studied. Finally, this also can help guiding pollution control actions in areas of greater susceptibility, prioritizing timely interventions in sensitive areas in the aftermath of accidents.

\section{Conclusions}

It was noticed that the variability of the oceanographic and meteorological conditions are sources of uncertainties in the susceptibility estimations of oil contamination. The reliability of susceptibility assessments could increase if it was based on a larger number of oil spill scenarios.

Three oil spill accidents, which started at buoy MN-602 in the coast of Rio Grande do Sul, Brazil in 2012, 2014 and 2016 were modelled. For all of them, the verified consistency between the modelled results and the information from technical reports of the accidents are favourable indicators of the benefits of applying the present methodology to similar studies for the characterization of oil spill-related processes in different areas.

Modelled results of evaporation shown to be consistent with reference literature values, varying $4 \%$ in the first hours to about $15 \% 24 \mathrm{~h}$ after the start of the spill. Regarding emulsification rates the mass increase of water content found was approximately $75 \%$ into the first hours after the oil spills, in agreement with the

${ }^{4}$ https://powerplants.man-es.com/fuels/hfo 
expected for the type of heavy fuel oil that spilt in the accidents examined. The emulsification curves showed that the algorithms that describe this process in the model need to be improved, either to not stabilize these rates at a level based on a coefficient or to take into account the resin and asphaltene content.

Modelled results of evaporation, emulsification and mass increase of the water-in-oil emulsions also shown to be consistent with reference literature values. This contributes with the understanding of the oil slicks behaviour due to small-scale accidents, which albeit more frequent, are still poorly studied. Finally, this information can help guiding pollution control actions in areas of greater susceptibility, prioritizing timely interventions in sensitive areas in the aftermath of accidents.

\section{Funding}

This study was partially financed by Coordenação de Aperfeiçoamento de Pessoal de Nível Superior Brasil (CAPES) and has Finance Code 001. We thank the resources provided by CAPES to support the Postgraduate Program in Oceanology. The authors also acknowledge the support of the CNPq and FAPERGS for sponsoring the research (contracts 304227/2016-1 and 17/2551-0001159-7).

\section{Acknowledgements}

The authors wish to thank the Brazilian Navy and GEBCO for the bathymetric dataset, ANA for the fluvial discharge data and ECMWF and HYCOM for the global reanalysis datasets. The authors would also like to thank the Open TELEMAC-Mascaret Consortium for the free distribution of TELEMAC-3D to the Federal University of Rio Grande (FURG) for the ECOS model and the National Supercomputing Center (CESUP) and the National Laboratory of Scientific Computing (LNCC) for allocating time for the use of their supercomputer systems.

\section{References}

D. Cormier, M. Magnan, Investors' assessment of implicit environmental liabilities: An empirical investigation, Journal of accounting and public policy 16 (1997) 215-241. doi: 10.1016/S0278-4254(97)00002-1.

J. Beyer, H. C. Trannum, T. Bakke, P. V. Hodson, T. K. Collier, Environmental effects of the Deepwater Horizon oil spill: A review, Marine Pollution Bulletin 110 (2016) 28-51. doi: 10.1016/j.marpolbul.2016.06.027.

M. Lee, J. Jung, Pollution risk assessment of oil spill accidents in Garorim Bay of Korea, Marine Pollution Bulletin 100 (2015) 297-303. doi: 10.1016/j.marpolbul.2015.08.037.

A. Azevedo, A. B. Fortunato, B. Epifânio, S. den Boer, E. R. Oliveira, F. L. Alves, G. de Jesus, J. L. Gomes, A. Oliveira, An oil risk management system based on high-resolution hazard and vulnerability calculations, Ocean \& Coastal Management 136 (2017) 1-18. doi: 10.1016/j.ocecoaman.2016.11.014.

H. J. Osofsky, J. D. Osofsky, T. C. Hansel, Deepwater Horizon oil spill: mental health effects on residents in heavily affected areas, Disaster Medicine and Public Health Preparedness 5 (2011) 280-286. doi: 10.1001/dmp.2011.85.

J. M. Gohlke, D. Doke, M. Tipre, M. Leader, T. Fitzgerald, A Review of Seafood Safety after the Deepwater Horizon Blowout, Environmental Health Perspectives 119 (2011) 1062-1069. doi: 10.1289/ehp.1103507.

U. R. Sumaila, A. M. Cisneros-Montemayor, A. Dyck, L. Huang, W. Cheung, J. Jacquet, K. Kleisner, V. Lam, A. McCrea-Strub, W. Swartz, R. Watson, D. Zeller, D. Pauly, Impact of the Deepwater Horizon well blowout on the economics of US Gulf fisheries, Canadian Journal of Fisheries and Aquatic Sciences 69 (2012) 499-510. doi: 10.1139/f2011-171.

R. D'adamo, S. Pelosi, P. Trotta, G. Sansone, Bioaccumulation and biomagnification of polycyclic aromatic hydrocarbons in aquatic organisms, Marine Chemistry 56 (1997) 45-49. doi: 10.1016/s0304-4203(96)00042-4.

H. Wang, X. Xia, R. Liu, Z. Wang, Y. Zhai, H. Lin, W. Wen, Y. Li, D. Wang, Z. Yang, D. C. G. Muir, J. C. Crittenden, Dietary uptake patterns affect bioaccumulation and biomagnification of hydrophobic organic compounds in fish, Environmental Science \& Technology 53 (2019) 4274-4284. doi: 10.1021/acs.est.9b00106.

Z. Xia, I. Idowu, C. Marvin, P. J. Thomas, W. Johnson, O. Francisco, J. Stetefeld, B. Crimmins, M. Fry, G. T. Tomy, Identification of halogenated polycyclic aromatic hydrocarbons in biological samples from Alberta Oil-Sands Region, Chemosphere 215 (2019) 206-213. doi: 10.1016/j.chemosphere.2018.10.050.

R. E. Struch, E. L. Pulster, A. M. Schreier, S. A. Murawski, Hepatobiliary Analyses Suggest Chronic PAH Exposure in Hakes (Urophycis spp.) Following the Deepwater Horizon Oil spill, Environmental Toxicology and Chemistry (2019). doi: 10.1002/etc. 4596 .

J. O. Akinola, O. O. Olawusi-Peters, V. O. E. Akpambang, Ecological hazards of Total petroleum hydrocarbon in brackish water white Shrimp Nematopalaemon hastatus (AURIVILLUS 1898), The Egyptian Journal of Aquatic Research (2019). doi: 10.1016/j.ejar.2019.07.004. 
S. J. Yoon, S. Hong, T. Kim, J. Lee, B. Kwon, A. A. Allam, A. A. Al-khedhairy, J. S. Khim, Occurrence and bioaccumulation of persistent toxic substances in sediments and biota from intertidal zone of Abu Ali Island, Arabian Gulf, Marine Pollution Bulletin 144 (2019) 243-252. doi: 10.1016/j.marpolbul.2019.05.008.

P. Wells, T. Höfer, M. Nauke, Evaluating the hazards of harmful substances carried by ships: The role of GESAMP and its EHS working group, Science of The Total Environment 237-238 (1999) 329-350. doi: 10.1016/s0048-9697(99)00147-3.

S. R. Noh, J.-A. Kim, H.-K. Cheong, M. Ha, Y.-K. Jee, M.-S. Park, K.-H. Choi, H. Kim, S.-I. Cho, K. Choi, D. Paek, Hebei Spirit oil spill and its long-term effect on children's asthma symptoms, Environmental Pollution 248 (2019) 286-294. doi: 10.1016/j. envpol.2019.02.034.

M. Ha, Modeling for the allocation of oil spill recovery capacity considering environmental and economic factors, Marine Pollution Bulletin 126 (2018) 184-190. doi: 10.1016/j.marpolbul.2017.11.006.

ITOPF, Oil Tanker Spill Statistics 2018. The International Tanker Owners Pollution Federation Limited, 2018. URL: https: //www.itopf.org/fileadmin/data/Documents/Company_Lit/Oil_Spill_Stats_2019.pdf.

J. E. Portmann, P. M. Connor, The toxicity of several oil-spill removers to some species of fish and shellfish, Marine Biology 1 (1968) 322-329. doi: 10.1007/bf00360784.

N. P. Ventikos, K. Louzis, P. Sotiralis, Oil pollution: Sustainable ships and shipping, in: Sustainable Shipping, Springer International Publishing, 2019, pp. 167-201. doi: 10.1007/978-3-030-04330-8_5.

J. Michel, M. Fingas, Oil Spills: Causes, consequences, prevention, and countermeasures, in: G. M. Crawley (Ed.), Fossil Fuels, World Scientific, 2016, pp. 159-201.

J. Allen, B. Walsh, Enhanced oil spill surveillance, detection and monitoring through the applied technology of unmanned air systems, International Oil Spill Conference Proceedings 2008 (2008) 113-120. doi: 10.7901/2169-3358-2008-1-113.

A. Berry, T. Dabrowski, K. Lyons, The oil spill model OILTRANS and its application to the celtic sea, Marine Pollution Bulletin 64 (2012) 2489-2501. doi: 10.1016/j.marpolbul.2012.07.036.

ITOPF, Use of booms in oil pollution response, Technical Information Paper 3 (2014a) 12. URL: http://www.itopf.org/fileadmin/ data/Documents/TIPS\%20TAPS/TIP_3_Use_of_Booms_in_Oil_Pollution_Response.pdf, accessed: 2019-09-09.

ITOPF, Use of dispersants to treat oil spills, Technical Information Paper 4 (2014b) 12. URL: http://www.itopf.org/fileadmin/ data/Documents/TIPS\%20TAPS/TIP_4_Use_of_Dispersants_to_Treat_Oil_Spills.pdf, accessed: 2019-09-07.

ITOPF, Use of skimmers in oil pollution response, Technical Information Paper 5 (2014c) 16. URL: http://www.itopf.org/ fileadmin/data/Documents/TIPS\%20TAPS/TIP_5_Use_of_Skimmers_in_0il_Pollution_Response.pdf, accessed: 2019-09-05.

W. Guo, Development of a statistical oil spill model for risk assessment, Environmental Pollution 230 (2017) 945-953. doi: 10.1016/j.envpol.2017.07.051.

I. Berenshtein, N. Perlin, C. H. Ainsworth, J. G. Ortega-Ortiz, A. C. Vaz, C. B. Paris, Comparison of the spatial extent, impacts to shorelines, and ecosystem and four-dimensional characteristics of simulated oil spills, in: Scenarios and Responses to Future Deep Oil Spills, Springer International Publishing, 2019, pp. 340-354.

T. M. Alves, E. Kokinou, G. Zodiatis, A three-step model to assess shoreline and offshore susceptibility to oil spills: The South Aegean (Crete) as an analogue for confined marine basins, Marine Pollution Bulletin 86 (2014) 443-457. doi: 10.1016/j.marpolbul.2014.06.034.

T. M. Alves, E. Kokinou, G. Zodiatis, R. Lardner, C. Panagiotakis, H. Radhakrishnan, Modelling of oil spills in confined maritime basins: the case for early response in the Eastern Mediterranean Sea, Environmental Pollution 206 (2015) $390-399$. doi: $10.1016 /$ j.envpol.2015.07.042.

G. Luan, S. Chu, X. Li, L. Wang, et al., Responding to Oil Spill of Inland River Water Crossing Pipeline: Successfully Handles Oil Spill, in: SPE Symposium: Asia Pacific Health, Safety, Security, Environment and Social Responsibility, Society of Petroleum Engineers, 2019. doi: 10.2118/195394-MS.

H. Meng, G. Chen, X. Liu, Y. Zhu, An oil recovery technique for emergency response in deepwater blowout accidents, Safety Science 113 (2019) 134-143. doi: 10.1016/j.ssci.2018.11.011.

C. B. Monteiro, P. H. Oleinik, B. V. Lopes, T. F. Leal, D. V. da Silva, O. O. Möller Jr, W. C. Marques, Reproducibility of a real case of an oil spill during vessel supply operation in an estuarine zone, Defect and Diffusion Forum 396 (2019) $121-131$. doi: $10.4028 /$ www.scientific.net/DDF.396.121.

J. H. Øksenvåg, M. Fossen, U. Farooq, Study on how oil type and weathering of crude oils affect interaction with sea ice and polyethylene skimmer material, Marine Pollution Bulletin 145 (2019) 306-315. doi: 10.1016/j.marpolbul.2019.05.021.

A. P. Institute, Fate Of Spilled Oil In Marine Waters: Where Does It Go? What Does It Do? How Do Dispersants Affect It?, Washington, D.C., 1999.

M. Fingas, A literature review of the physics and predictive modelling of oil spill evaporation, Journal of Hazardous Materials 42 (1995) 157-175. doi: 10.1016/0304-3894(95) 00013-K.

M. Fingas, The evaporation of oil spills: development and implementation of new prediction methodology, in: International Oil Spill Conference, 1, American Petroleum Institute, 1999, pp. 281-287. doi: 10.7901/2169-3358-1999-1-281.

M. Reed, E. Gundlach, T. Kana, A coastal zone oil spill model: development and sensitivity studies, Oil and Chemical Pollution 5 (1989) 411-449. doi: 10.1016/S0269-8579(89)80019-X.

M. F. Fingas, B. Fieldhouse, J. Lane, J. V. Mullin, What causes the formation of water-in-oil emulsions?, in: International Oil Spill Conference, 1, American Petroleum Institute, 2001, pp. 109-114. doi: 10.7901/2169-3358-2001-1-109.

M. Fingas, Studies on the evaporation of crude oil and petroleum products: I. The relationship between evaporation rate and time, Journal of Hazardous Materials 56 (1997) 227-236. doi: 10.1016/s0304-3894 (97)00050-2.

M. Fingas, C. Brown, A review of oil spill remote sensing, Sensors 18 (2018) 91. doi: 10.3390/s18010091.

A. K. Mishra, G. S. Kumar, Weathering of oil spill: modeling and analysis, Aquatic Procedia 4 (2015) 435-442. doi: 10.1016/j. aqpro. 2015.02.058.

W. C. Marques, C. E. Stringari, E. P. Kirinus, O. O. Möller, E. E. Toldo, M. M. Andrade, Numerical modeling of the 
Tramandaí beach oil spill, Brazil—case study for January 2012 event, Applied Ocean Research 65 (2017) 178-191. doi: $10.1016 / \mathrm{j}$.apor.2017.04.007.

M. M. de Mahiques, S. H. d. M. Sousa, V. V. Furtado, M. G. Tessler, F. A. d. L. Toledo, L. Burone, R. C. L. Figueira, D. A. Klein, C. C. Martins, D. P. V. Alves, The Southern Brazilian shelf: general characteristics, quaternary evolution and sediment distribution, Brazilian Journal of Oceanography 58 (2010) 25-34. doi: 10.1590/\$1679-87592010000600004.

O. O. Möller Jr, P. Castaing, J. Salomon, P. Lazure, The influence of local and non-local forcing effects on the subtidal circulation of Patos Lagoon, Estuaries 24 (2001) 297-311. doi: 10.2307/1352953.

C. P. Dereczynski, W. F. Menezes, Meteorologia da bacia de campos, in: Meteorologia e Oceanografia, Elsevier, 2015, pp. 1-54. doi: 10.1016/B978-85-352-6208-7.50008-8.

P. Zavialov, O. O. Möller Jr, E. Campos, First direct measurements of currents on the continental shelf of southern Brazil, Continental Shelf Research 22 (2002) 1975-1986. doi: 10.1016/S0278-4343(02)00049-3.

J. L. Stech, J. A. Lorenzzetti, The response of the South Brazil Bight to the passage of wintertime cold fronts, Journal of Geophysical Research: Oceans 97 (1992) 9507-9520. doi: 10.1029/92jc00486.

L. J. Calliari, J. C. Winterwerp, E. Fernandes, D. Cuchiara, S. B. Vinzon, M. Sperle, K. Holland, Fine grain sediment transport and deposition in the Patos Lagoon-Cassino beach sedimentary system, Continental Shelf Research 29 (2009) 515-529. doi: $10.1016 / j . c s r .2008 .09 .019$.

L. Tomazelli, J. Villwock, Considerações sobre o ambiente praial e a deriva litorânea de sedimentos ao longo do litoral norte do Rio Grande do Sul, Brasil, Pesquisas em Geociências 19 (1992) 3-12.

J. L. Nicolodi, Atlas de Sensibilidade Ambiental ao Óleo da Bacia Marítima de Pelotas, Ministério do Meio Ambiente, Secretaria de Mudanças Climáticas e Qualidade Ambiental, Departamento de Qualidade Ambiental, Gerência de Qualidade Costeira e do $\mathrm{Ar}, 2016$.

W. Horn, Boletim Técnico Petrobrás - O sistema de monobóia como solução para os terminais em mar aberto, Technical Report 2, Petrobrás, 1969.

J. M. Hervouet, Free surface flows: modelling with the finite element methods, John Wiley \& Sons, 2007. doi: 10.1002/ 9780470319628

L. F. Mello, C. E. Stringari, R. T. Eidt, W. C. Marques, Desenvolvimento de um Modelo Lagrangiano de Transporte de Óleo: Estruturação e Acoplamento ao Modelo Hidrodinâmico TELEMAC-3D, in: P. Sausen (Ed.), Pesquisas Aplicadas em Modelagem Matemática, volume 1, Editora Unijui, 2011, pp. 1-21.

C. E. Stringari, W. C. Marques, R. T. Eidt, L. F. Mello, Modeling an oil spill along the Southern Brazilian Shelf: forcing characterization and its influence on the oil fate, International Journal of Geosciences 04 (2013) 397-407. doi: 10.4236/ijg. 2013.42038.

C. B. Monteiro, E. d. P. Kirinus, W. C. Marques, P. H. Oleinik, J. Costi, Analysis of two oil spills in the Southern Brazilian Shelf, in the years of 2012 and 2014, Defect and Diffusion Forum 372 (2017) 70-80. doi: 10.4028/www.scientific.net/DDF.372.70.

W. Stiver, D. Mackay, Evaporation rate of spills of hydrocarbons and petroleum mixtures, Environmental Science and Technology 18(11) (1984) 834-840. doi: 10.1021/es00129a006.

W. Lehr, R. Jones, M. Evans, D. Simecek-Beatty, R. Overstreet, Revisions of the ADIOS oil spill model, Environmental Modelling \& Software 17 (2002) 189-197. doi: 10.1016/S1364-8152(01)00064-0.

D. Mackay, B. K. Trudel, S. Paterson, C. E. I. C. Directorate, C. E. E. B. Research, D. Division, A Mathematical model of oil spill behaviour, Research and Development Division, Environmental Emergency Branch, Canada, 1980.

D. Mackay, W. Y. Shiu, K. Hossain, W. Stiver, D. McCurdy, Development and calibration of an oil spill behavior Model, Technical Report, Toronto University (Ontario) Dept of Chemical Engineering and Applied Chemistry, 1982.

C. Torrence, G. P. Compo, A practical guide to wavelet analysis, Bulletin of the American Meteorological Society 79 (1998) 61-78.

FEPAM, Environmental Technical Report No 01/2012/MB-IBAMA-FEPAM, Technical Report, FEPAM, 2012.

FEPAM, Environmental Technical Report No 05/12/2014-SEAMB - Acknowledgment Report, Technical Report, FEPAM, 2014.

FEPAM, Environmental Technical Report - Acknowledgment Report, Technical Report, FEPAM, 2016.

A. Urbahs, V. Zavtkevics, Oil spill detection using multi remote piloted aircraft for the environmental monitoring of sea aquatorium, Environmental and Climate Technologies 24 (2020) 1-22. doi: 10.2478/rtuect-2020-0001.

J. Janeiro, E. Fernandes, F. Martins, R. Fernandes, Wind and freshwater influence over hydrocarbon dispersal on Patos Lagoon, Brazil, Marine Pollution Bulletin 56 (2008) 650-665. doi: 10.1016/j.marpolbul.2008.01.011.

E. d. P. Kirinus, P. H. Oleinik, J. Costi, W. C. Marques, Long-term simulations for ocean energy off the Brazilian coast, Energy 163 (2018) 364-382. doi: 10.1016/j.energy.2018.08.080.

C. K. Parise, L. J. Calliari, N. Krusche, Extreme storm surges in the south of Brazil: atmospheric conditions and shore erosion, Brazilian Journal of Oceanography 57 (2009) 175-188. doi: 10.1590/\$1679-87592009000300002.

M. M. Andrade, E. E. Toldo Jr, J. C. Nunes, Variabilidade das correntes na plataforma interna ao largo de Tramandaí, RS durante o verão de 2014, Pesquisas em Geociências 43 (2016) 289-298. doi: 10.22456/1807-9806.78231.

J. M. Saraiva, C. Bedran, C. Carneiro, Monitoring of storm surges on Cassino Beach, RS, Brazil, Journal of Coastal Research (2003) 323-331. doi: https://www.jstor.org/stable/40928778.

H. Hasenack, L. Ferraro, Considerações sobre o clima da região de Tramandaí, RS, Pesquisas em Geociências 22 (1989) 53-70. doi: $10.22456 / 1807-9806.21456$.

R. P. da Rocha, S. Sugahara, R. B. da Silveira, Sea waves generated by extratropical cyclones in the South Atlantic Ocean: Hindcast and validation against altimeter data, Weather and forecasting 19 (2004) 398-410. doi: 10.1175/1520-0434(2004) $019<0398$ : SWGBEC>2.0. C0;2.

B. V. Lopes, A. Pavlovic, T. B. Trombetta, P. H. Oleinik, C. B. Monteiro, R. C. Guimarães, D. V. da Silva, W. C. Marques, Numerical Study of Oil Spill in the Patos Lagoon Under Flood and Ebb Conditions, Journal of Marine Science and Engineering 
7 (2019) 4. doi: 10.3390/jmse7010004.

C. B. Monteiro, P. H. Oleinik, B. V. Lopes, T. F. Leal, O. O. Möller Jr, W. C. Marques, Oil spill simulations and susceptibility in coastal and estuarine areas, Defect and Diffusion Forum 396 (2019) 109-120. doi: 10.4028/www.scientific.net/DDF.396.109.

T. F. Leal, C. B. Monteiro, M. C. Silva, O. O. Möller Jr, P. H. Oleinik, W. C. Marques, Numerical study of oil spill in the patos lagoon estuary region, Revista de Engenharia Térmica 18 (2019) 22. doi: 10.5380/reterm.v18i1.67026.

MMA, Especificações e normas técnicas para a elaboração de Cartas de Sensibilidade Ambiental para derramamentos de óleo, 1 ed., Brasília, 2002.

J. R. Jensen, J. N. Halls, J. Michel, A systems approach to Environmental Sensitivity Index (ESI) mapping for oil spill contingency planning and response, Photogrammetric Engineering and Remote Sensing 64 (1998) 1003-1014.

J. Petersen, J. Michel, S. Zengel, M. White, C. Lord, C. Plank, Environmental Sensitivity Index Guidelines. Version 3.0, NOAA Technical Memorandum NOS OR\&R 11 (2002) 1-192.

A. Wieczorek, D. Dias-Brito, J. C. C. Milanelli, Mapping oil spill environmental sensitivity in Cardoso Island State Park and surroundings áreas, São Paulo, Brazil, Ocean \& Coastal Management 50 (2007) 872-886. doi: 10.1016/j.ocecoaman.2007.04.007.

R. M. Pinheiro, M. D. da Silva, Threatened landscapes of the restinga da Lagoa dos Patos (RS): landscape ecology as contribution to the economic ecological zoning of the middle coast, Geographia Meridionalis 4 (2019) 269-299. doi: 10.15210/gm.v4i2.14483.

M. Fingas, Evaporation modeling, volume 2011, International Oil Spill Conference, 2011, p. abs6. doi: 10.7901/2169-3358-2011-1-6.

X. Chao, N. J. Shankar, H. F. Cheong, Two-and three-dimensional oil spill model for coastal waters, Ocean engineering 28 (2001) 1557-1573

M. Badri, A. Azimian, Oil spill model based on the Kelvin wave theory and artificial wind field for the Persian Gulf (2010).

R. d. Vos, Comparison of 5 oil-weathering models, Rapportnr.: ZD/2005.011 w (2005).

J. D. McLean, P. K. Kilpatrick, Effects of asphaltene solvency on stability of water-in-crude-oil emulsions, Journal of Colloid and Interface Science 189 (1997) 242-253.

J. Djuve, X. Yang, I. J. Fjellanger, J. Sjöblom, E. Pelizzetti, Chemical destabilization of crude oil based emulsions and asphaltene stabilized emulsions, Colloid \& Polymer Science 279 (2001) 232-239. doi: 10.1007/s003960000413.

D. Mackay, I. Buist, R. Mascarenhas, S. Paterson, Oil spill processes and models, Environment Canada Manuscript Report No. EE-8, Ottawa, Ontario (1980). 